\title{
Travel Account of Nasser Khosrow Qobâdiâni or Daily Accounts of an Anthropologist in Retrospect
}

\begin{abstract}
In this article the author claims that there is good reason to search in Iranian scholarly writings to find the origins of anthropology in retrospect. The author claims that the intentions of Nasser Khosrow Qobâdiyani were different from that of a student of anthropology when he/she sets out to do research to become an anthropologist, but the descriptions of what he sees are very important for various subfields of anthropology today. Nasser Khosrow paid particular attention to city planning, architecture, interior decoration of various sites, and then to water and uses of rain water, agriculture and herding. He described in great detail locations of pilgrimage where he performed what was expected, and he also gave minute descriptions of celebrations across various classes, and various ethnic and religious groups.
\end{abstract}

Keywords: Nasser Khosrow, anthropology, crisis, similarities, differences, details, subfields of anthropology

A Study of Nasser Khosrow's Safarnâmeh shows us that the text consists of his daily observations of his seven years travel. He writes on environment, architecture, art, economy and politics of various rural and urban locations. He pays little attention to social matters, and his emotional reactions and intellectual searches are occasionally if ever mentioned.

Today's anthropological research requires at least one year stay in a location, different from the researcher's abode, before he can write his thesis. A scholar keeps daily notes, besides engaging in interviews which are kept separately.

Safarnâmeh of Nasser Khosrow is a report from when he started his journey to all locations he passed through. Primarily this is different from a daily notebook of an anthropologist, as the latter is concentrated in one location, the actual place of his/her research. As we shall see this text has detailed information on rural and urban areas which are unique and we cannot over look it as a text which came before first academic anthropological endeavors in Europe by some 750 years. 
Is it a viable search that we look at such an ancient text to find similarities to a modern science? The response to this question is, I think, positive because I believe although anthropology is a modern science, yet its search for meaning, for better governance as we shall see with Nasser Khosrow started at the dawn of civilization. Although questions regarding meaning of being human and philosophy of life existed before civilization started ${ }^{1}$, but for the human being who started to live in civilization with a written alphabet, social classes, central power, beginning of cruelties toward others, under-classes and slaves also started and the origin of the first written questions regarding justice and diversity of various forms of government also started. Hereby, questions regarding the viability of different forms of governing people were posed.

Stanley Diamond, anthropologist, called anthropology "the study of man, [it] is actually the study of men in crisis by men in crisis". ${ }^{2}$ This definition is part and parcel of Safarnâmeh as Nasser Khosrow was a man in turmoil, and while he was traveling he was looking to find responses to his quests. He was not doing research about other societies, he was deeply angry with his own society, and he left for seven years, trying to find responses to his inner search. He had been working as a man of state with highest responsibilities, but he was angry, as all intellectuals, and it is only what he writes inadvertently that is so precise in details which have become noteworthy as a descriptive text of a very rational mind. He does not share with the reader his personal quests, as Jean-Jacque Rousseau, believed to be forefather of anthropology, does in his various writings, he totally separates himself as a man in crisis from the author of Safarnâmeh. In his text he only mentions his opinion about a few individuals to whom we shall refer later.

It is thus absolutely meaningful for anthropology to search in books and manuscripts of Iranian culture to find authors whose quests were similar to what came centuries afterwards and posed the basic theoretical questions of anthropology.

Another reason why we should attend to such texts is that whenever the history of anthropology is evoked, mention is made of its first texts having been written by the first colonial powers. This qualification gives a negative tone to the history of anthropology. Why not search in texts unrelated to colonialism for finding those authors who were searching for the real meaning of anthropology, or whose endeavors were similar to what later became anthropology? This is where we see human beings, the learned of various cultures, engage in essential quests related to human existence. Anthropology with its search into human nature, tries to find societies where justice was prevalent, and human nature was coordinated with society in a way that justice could be exercised, and cruelty and injustice did not reign. At the time when law was to be written by human beings, knowledge of human nature was deemed necessary in order to write laws which would do justice to all. This quintessential question goes opposite the colonial endeavor, and we will be doing more justice to the spirit of anthropology if we search in texts of all cultures to find those scholars who were engaging in such a search. This type of

\footnotetext{
1 P. Radin, Primitive Man as Philosopher, Dover 1927/1957.

2 S. Diamond, In Search of the Primitive, Dutton 1974, p. 93.
} 
research could find the raison d'être of this field in different cultures of the world and would give further credence to the field.

\section{Safarnâmeh or Daily Accounts}

The beginning of Nasser Khosrow's travels started with dissatisfaction. This state was not dissatisfaction of a young man who was just facing the socio-economic and political problems for the first time, rather it was those of a man of state, who had been in the state apparatus with considerable responsibilities. He left his abode and his position in quest of essential questions which had risen out of his experience in his official capacities. Although he considered himself to be a rational man, yet his capabilities were not "true capacity (tavângari-ye haqiqi)". This is why he set out on a voyage. Similar to many inward human upheavals of particular personalities in human history, his search started with a call, with a dream and a voice which advised him to travel. Nasser Khosrow thus set out for a journey which had a sense of direction, the voice had indicated that he should take the direction of Mecca. It is with this aim that at the age of forty he set out. He said he woke up after a forty-year slumber through change in his deeds and activities to find real wisdom.

As mentioned above, in anthropology a doctoral student must make a journey of at least a year to a different location than where he is used to live. Taking distance from one's culture and everyday life is a necessity for understanding what culture is, and this enables the student to begin and think in terms of another culture, and this helps him realize how different cultures can experience the world differently and survive. In the written history of Western civilization, we repeatedly see philosophers write after they have taken long journeys, Descartes and Rousseau write about this having been essential for their later writings.

Nasser Khosrow gives a quantified account of his journey, he gives the date of his departures, and the distance between different locations that he travels, he describes villages and urban centers. He describes what he sees on the roads, and even what he smells with great precision, and what is noteworthy is how he counts and gives calculated measures of all he finds to be important. He gives the population of various locations, and the prices of food stuff and in cases of drought, again he mentions the prices.

First let us see a few of his quantified descriptions, leaving the rest to the interested reader to follow in the text: The earthquake in Tabriz killed 40,000 people. ${ }^{3}$ The city of Âmed, (Diârbakr), had four gates in the four basic directions. The city pond was $10 \mathrm{gaz}$ [1 $\mathrm{gaz}$ is approximately $1 \mathrm{~m}-\mathrm{SS}$ ] measuring unit in perimeter. ${ }^{4}$ Damascus and its vicinity used pillars in buildings, and 500,000 pillars or heads of pillars were counted by him. ${ }^{5}$

\footnotetext{
${ }^{3}$ Nâser-e Khosrow-e Qobâdiyâni, Safarnâme, ed. M. Dabir Siaqi, Tehrân 1389/2006, p. 8.

${ }^{4}$ Ibidem, p. 8.

5 Ibidem, p. 22.
} 
In the city of Tabarieh, under a mosque, there was a store underneath were 70 tombs belonging to prophets who were annihilated by the Jews were located. ${ }^{6}$ In the city of Bethlehem, in a ceremony, 20,000 boys were circumcised. ${ }^{7}$ Each prayer said in the city of Bethlehem was worth 25,000 prayer in ordinary locations. In the city of Medina it would be worth 50,000 and in Mecca 100,000. ${ }^{8}$

To pilgrims to the tomb of prophet Abraham, even if they were 500 per day, a bowl of lentil soup, grapes and a piece of bread would each be offered. ${ }^{9}$ The church of Bethlehem held 8,000 people. ${ }^{10}$ The population of the coastal city of Masâne' was 50,000 men and 1,000 ships were anchored there. An armed troop were stationed there and sent 1,000 dinars daily to the treasury of the King. ${ }^{11}$

The level of the Nile River is ordinarily 18 arash $[52-55 \mathrm{~cm}-\mathrm{SS}]$ and if it goes lower, people make offerings so that it would increase. ${ }^{12}$ The water of the Nile River floods the grounds around it for four months. ${ }^{13}$ In the city of Cairo the king rented 20,000 shops and 8,000 houses. ${ }^{14}$ There were 1,000 guards at night for the city of Cairo, 500 on horseback, 500 on foot. There were 12,000 paid workers. The inhabitants of the fortress were 30,000 , but the number of women and female slaves was not clear. In the fortress twelve buildings with specific names existed. ${ }^{15}$

The water of the Nile River was carried to individual houses by 50,000 camels. ${ }^{16}$ The descriptions of the houses in Cairo are amazing as there are some up to 14 floors, with seven calves on the roofs for irrigating the roof-gardens which had citrus and banana trees). ${ }^{17}$ At the mosque, bazaar and school, there were, at every moment, some 5,000 scribes and theologians..$^{18}$ The light holder of mosque, has 16 sides and the length of each side is 5.1 arash. The circumference of the light is 24 arsh and more than 700 lamps can be placed therein, but generally 100 of them are lighted. ${ }^{19}$

Armenians of Egypt were wealthy to the extent that during a year of famine, they provided bread for six years of the people. ${ }^{20}$

During the famine of the city of Hejaz, 35,000 people went to Egypt and the king gave them refuge. ${ }^{21}$ The Sultan had a servant who searched antiquity belong-

\footnotetext{
${ }^{6}$ Ibidem, p. 29.

${ }^{7}$ Ibidem, p. 33.

${ }^{8}$ Ibidem, p. 55.

${ }^{9}$ Ibidem, p. 60.

${ }^{10}$ Ibidem, p. 62.

${ }^{11}$ Ibidem, p. 65.

12 Ibidem, p. 68

13 Ibidem, p. 70.

14 Ibidem, p. 76.

15 Ibidem, p. 77.

16 Ibidem, p. 78.

${ }_{17}$ Ibidem, p. 89.

18 Ibidem, pp. 90-91.

${ }_{19}$ Ibidem, p. 91.

${ }^{20}$ Ibidem, p. 96.

${ }^{21}$ Ibidem, p. 104.
} 
ing to the Pharao and whatever he found, he gave one fifth to the Sultan. ${ }^{22}$ After the death of this servant, all his property went to the treasury of the Sultan, and 300 female slaves whom he possessed, were freed. ${ }^{23}$

The city of Lahsâ had 20,000 military men, 30,000 peasants who were originally from Ethiopia and Zanzibar, and one tenth of the production was sent to the Sultan. ${ }^{24}$ Bassreh had 20 regions and because of the dangers which surrounded it due to the depth of water, some 400 ships filled with date pits, were ordered to be drowned there. ${ }^{25}$ To be discussed later, also. Nasser Khosrow returned to his natal city of Balkh after seven years. ${ }^{26}$

\section{Topics of Interest to Nasser Khosrow}

\section{Water}

He paid particular attention to water sources and rain, and the use which was made of water in rural and urban areas. The source of water of the city of Âmed, Diârbekr, came from granite (sang-e khârâ), and the quality was very good. In the mosque of the city, there was a round pool, which had the height of human being, and circumference $10 \mathrm{gaz}$. It had fountains and the entry and exit of water could not be seen. ${ }^{27}$

The city of Seidâ was built on heights and the water of the city was provided by the mountain. The water was conducted over the roofs of the houses. ${ }^{28}$ On the Eastern front of the city of Meinâ, 'Ein ol-Baqar Fountain where the Prophet Adam had given water to its cow still existed. ${ }^{29}$

The water near the city of Tabarieh is good and refreshing, and it flew toward a valley, creating a lake, where the city was constructed. ${ }^{30}$ This city was constructed on a stone slab which was under the water. Columns were built to hold the city and they could be seen in the water. The mosque used the source water and the bath house was constructed at the origin of this source, and its water was mixed with cold water to be usable. ${ }^{31}$ In the city of Bethlehem rain water was used, because the city was built on stone; in the surrounding villages, there were sources. The passage of rain water over stones, made them become clean and shiny. ${ }^{32}$ In Sâhere again source water came out of stone, and people would take their baths

\footnotetext{
22 Ibidem, p. 107.

23 Ibidem, p. 108.

24 Ibidem, p. 148.

25 Ibidem, p. 160.

26 Ibidem, p. 172.

27 Ibidem, p. 13.

28 Ibidem, p. 22.

29 Ibidem, p. 25.

30 Ibidem, p. 28.

31 Ibidem, p. 29.

32 Ibidem, p. 36.
} 
close to these sources. This water cured lots of diseases and vaqf-monetary support for this source was given to protect it..$^{33}$

At the mosque of Masjed ol-Aqsâ a pond gathered rain water which was used for ablutions. Besides this, there were other ponds and water catchers which protected water so that it would not be wasted. In the vicinity of Bethlehem there was a great water pond which held the water which came from the mountains, and it was then directed toward the city. In every house there was a granite pond. The entrance of these ponds was small like that of an oven so that unwanted objects would not fall into them..$^{34}$

During the annual celebration of Conquest of the Gulf, the Sultan and the dignitaries would offer food, and yearly distribution of water would take place at this time.$^{35}$ Every brass water container held 30 man [ 1 man is approximately $3 \mathrm{~kg}-\mathrm{SS}$ ] of water, and this is how water was carried. ${ }^{36}$

Near the Lut Desert, between Garmeh and Tabas, every 2 farsangs [1 farsang is approximately $6 \mathrm{~km}-\mathrm{SS}$ ], there were small domes and underneath the domes water would gather. ${ }^{37}$ In the city of Tun, there was an underground aquaduct. ${ }^{38}$

We thus can conclude that Nasser Khosrow paid great attention to water in urban areas where it had paramount importance, its origin, its flow and the issuing sewage system. So urban anthropology of the Middle East which searches the relation between nature-human being-and built space must pay attention to this text.

\section{Agriculture and Herding}

Water, agriculture and herding have direct links, so we can focus for a moment on agriculture and herding. Crossing the city of Van toward Vostân, Nasser Khosrow sees sheep and pig meat were sold..$^{39}$ The cities of Arâzan and Âmed (Diarbakr) had plenty of water, and thus there were lots of trees and vineyards. ${ }^{40}$ The city of A'amar at-al-No'mân produced wheat, figs, olives, pistachios, almonds and grapes. ${ }^{41}$ In the vicinity of the city of Trablos, sugar cane, citrus trees, bananas, and dates were planted. ${ }^{42}$

Jabal, besides palm trees and other trees of warm climate, also had red and white roses, and on the $24^{\text {th }}$ of February this flower was seen in children's hands, ${ }^{43}$ and this shows that they were engaged in some kind of ceremony.

\footnotetext{
33 Ibidem.

34 Ibidem, p. 43.

35 Ibidem, p. 86.

36 Ibidem, p. 93.

37 Ibidem, p. 168.

38 Ibidem, p. 170.

39 Ibidem, p. 9.

40 Ibidem, p. 10.

41 Ibidem, p. 13.

42 Ibidem, p. 20.

43 Ibidem, p. 21.
} 
In the city of 'Ake they were raising garden vegetables a reminder of the Prophet Adam who had plantations there. ${ }^{44}$

Tabarieh was built over stone slabs, and around its stores and mosques, shrubs of jasmine were planted. They smelled so deliciously that the mosque of Tabarieh was called Jasmine Mosque. In order to prevent âfâtzadegi of trees, they used a foam which surfaced from the sea near the city of Tabarieh, and tore this foam which stretched to pieces and buried it under the tree. Spice stores used this same remedy against worms which threatened their medicinal plants. ${ }^{45}$

In Qeisarieh and all along the road between Kafrsaba and Ramallah, and around Bethlehem they had fig and olive trees planted. In Ramallh barley and not wheat was planted. ${ }^{46}$

Spring and winter vegetables and orchards were common around the cities by the Nile River, ${ }^{47}$ and pastures for herds were used by "black men" who were tall and slender, ${ }^{48}$ thus most probably were the Dinka.

A very interesting matter about Cairo were its roof gardens. ${ }^{49}$ Nasser Khosrow found houses which were seven floors, had citrus and banana trees on their roofs. In order to irrigate them, a calf was taken to the roof when small, and as it grew older it was taught to do the work of turning around the well and pulling out water to the seventh floor. ${ }^{50}$ In Egypt from the following plants oil was extracted: beet, turnip, sesame seeds and olives, almonds and pistachios. ${ }^{51}$ Opium was from the city of Asiuth, and was made from puppies which had small black seeds. ${ }^{52}$ Melons were the products of the city of Asvân, an actual island, besides dates and olives. ${ }^{53}$

In Mecca, in different seasons, there were different fruits: In February there were cucumbers and eggplants, in April there were grapes, and then melons and thus in different seasons there were various fruits and vegetables. ${ }^{54}$

Close to the city of Tâ'ef, the pasture of each tribe was clearly separated and if anyone surpassed his territory, he would be caught and as punishment his clothing would be taken off. ${ }^{55}$

In Lahsâ, there were slaves from Zanzibar who worked in gardens. ${ }^{56}$ The variety of meat which were consumed in this city were cow, sheep, donkey, dog and cat. There was so much date produced that they gave them to the animals also. ${ }^{57}$

\footnotetext{
44 Ibidem.

45 Ibidem, p. 29.

46 Ibidem, p. 32, 34, 60.

47 Ibidem, pp. 70-71.

48 Ibidem, p. 74.

49 Ibidem, p. 80.

50 Ibidem, p. 89.

51 Ibidem, p. 95.

52 Ibidem, p. 109.

53 Ibidem, p. 111.

${ }^{54}$ Ibidem, p. 141.

55 Ibidem, p. 142.

56 Ibidem, p. 148.

57 Ibidem, p. 151.
} 


\section{Crafts and Techniques}

Nasser Khosrow says: "More than any other profession, there are cobblers." 58 So any research about clothing must have a close look at this text.

The city of Sur on the coast, like Damascus used tar a $\operatorname{lot}^{59}$ in construction, and there were fine productions of silver and gold particularly in embellishments to light holders. Weaving straw objects was common in the city of Tabarieh. ${ }^{60}$ In Bethlehem buildings were made of stone, and there was no mud or other material to fill the space in between (exactly like buildings of Sassanid period). ${ }^{61}$ Use of enamel in plaster was very stunning, and brass doors from Damascus and columns and ceilings from stone without mud and plaster had surprised him. Again use of gold and enamel as embellishment in buildings is mentioned. ${ }^{62}$

He pays particular attention to city planning and architecture, to ponds made underground, to stone masonry, to roads, to columns and rain water pipes, doors, light holders which should be considered by all architectural anthropologists. ${ }^{63}$

In Bethlehem weaving cloth for fine turbans and for covering women's faces, which was called "vaqâye" (were in different colors) and the head cloth [dastâr] of Sultan and another kind of fine cloth of various colors called "buqalamun" were also woven here. ${ }^{64}$ They also wove a certain cloth for camels and for horses. They also made saddles from felt. ${ }^{65}$

At the time of yearly celebration when people of various professions and classes marched or walked in front of Sultan, they were distinct according to their clothing: Men of learning wore white long shirts called "dabiqi" (called "dârâ' $i$ " in Persian of his time), men of Deilam wore gold inlaid clothing, they had waist bands and large sleeves. ${ }^{6}$ Pâtâbe was wound around their legs, and the umbrella holder of the Sultan wore head cloth which had golden threads and jewels. Even the ship which was carrying the Sultan was embellished with satin cloth, gold and jewels. ${ }^{67}$

Light holders and chandeliers were made of silver, and a section of the bazaar was called "suq ol-qanâdil" where they were sold. In this section of the bazaar a predecessor of globalization is seen as there are objects from many different areas of the world: from local chickens and honey, to ivory from India, cow skin, trunks for jewelry, crystal knife handles, ceramics from Egypt and brass bowls from Damascus. ${ }^{68}$

\footnotetext{
58 Ibidem, p. 5.

59 Ibidem, p. 24.

60 Ibidem, p. 30.

61 Ibidem, p. 39.

62 Ibidem, p. 55.

63 Ibidem, p. 61.

64 Ibidem, p. 64.

65 Ibidem, p. 65.

${ }^{66}$ Ibidem, p. 85.

${ }^{67}$ Ibidem, p. 87.

${ }^{68}$ Ibidem, pp. 92-93.
} 
Ship and boat building industry was very involving, as in Cairo people used these means of transportation more than they did in Bassreh. ${ }^{69}$ Nasser Khosrow also wrote about the art of packaging, when he spoke of various trunks which were made to carry different objects, spices and liquids which were transported far and wide. ${ }^{70}$ When describing the kitchen of Sultan, he spoke about various spices and drinks which were given to the sick searching for remedies.

In order to light places where it was not possible to place a light, a slab of glass was placed on the ceiling, and rain water could also not penetrate, which shows production of thick glass at this time. ${ }^{71}$ I have observed use of thin marble pieces in the city of Kerman and in the grotto village of Meymand to light bath spaces. ${ }^{72}$ In Bahrein, pearl diving was a profession. ${ }^{73}$

\section{Relationship of Special Places with Human Beings}

He paid particular attention to pilgrimage sites and he would do whatever the prophets and their dependents had done in that space to show his dedication:

His praying where Zakariya had prayed, ${ }^{74}$ and repenting by Solomon's door where repentance of David was accepted, ${ }^{75}$ and his laying his finger on the column where Mary, Jesus's mother, had laid her fingers at the moment of giving birth, ${ }^{76}$ all these show his deep belief in these religious personalities, and his craving for redemption. Near Masjid ol-Harâm, in the market where the spice shops are located, the house of Prophet Mohammad was in an alley, and there was a door which led to the Mosque and "entering the mosque from this door, on the eastern wall, there is another door which was used by Imam Ali to go for prayers". ${ }^{77}$ According to him people would try and pray in the same location that the Prophet had prayed. ${ }^{78}$

In another location, in a hollow terrain, where there was a well and the prophet had made bread from flour, people would make bread there and consider it holy and carry it with them. ${ }^{79}$ The location where Balâl Habashi had prayed and the mosque which was built by Prophet Abraham, ${ }^{80}$ all of these were locations where he believed should pray. ${ }^{81}$ All these locations which were marked by spherical stones over tombs, were touched by him or he rubbed his hand on these places, or bowed to them, as to become close to these persons who could mediate between him and God just as it is exercised today in holy locations in Iran.

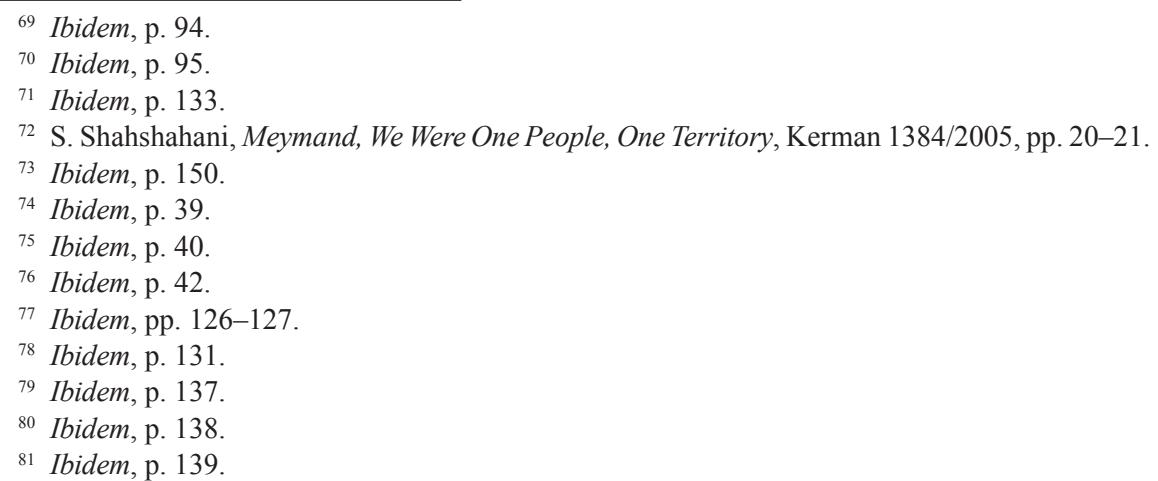




\section{Human Beings}

Let us now see what Nasser Khosrow says of people he sees on the road and in special locations. In a few places he speaks of children: In the city of Jabal he sees a number of kids walking with white and red roses in their hands. ${ }^{82}$ In Bethlehem, boys up to 20,000, would be circumcised in a group ceremony. ${ }^{83}$ Nasser Khosrow describes the games played by boys in streets of Cairo, ${ }^{84}$ but the age of kids is not mentioned. Bearing sons was apparently ceremoniously marked, as when the wife of the king of Cairo bore a son, the city was ceremoniously embellished and the people engaged in joyous feasts. ${ }^{85}$

In the city of Bajâviân between Egypt and Ethiopia, where people held no religions, had no prophets or believed in no particular person or creed, there was no stealing, plunder or pillage. Moslems would steal their children and sell them in their own cities. ${ }^{86}$

Very little is said about women by Nasser Khosrow, but let us consider what they are. First he talks about the daughter of Sho'eib, wife of Prophet Moussa. Then he talks of the tomb of Prophet Moussa's mother. ${ }^{87}$ In Bethlehem he talks of Saint Mary, mother of Prophet Jesus, ${ }^{88}$ also, he talks about the coffin of Saint Sakina, and that it was taken by the angels. ${ }^{89}$ Outside Bethlehem he went to the pilgrimage of tomb of the wife of Isaac son of Abraham. And mentions the floor cover which was made of woven straw from Morocco..$^{90}$ The tomb of Prophet Abraham's wife - Rahill - was close to that of Prophet Abraham. ${ }^{91}$

When writing about Cairo, he mentions that he does not know the number of women and female slaves ${ }^{92}$ and only mentions that "it is said that 30,000 inhabit the fortress". ${ }^{93}$ Silence about ordinary women, and few words about women related to men of religious position and then to their tombs comes from the fact, "no women would go outside the homes", 94 thus were not seen by Nasser Khosrow during his journeys. A few places he talks about female slaves, and once he speaks about liberating 300 female slaves. ${ }^{95}$ The most positive example he gives is about a woman official who had ordered that 400 ships with date pits be drowned so that the sea of Bassreh would be passable. ${ }^{96}$ This report shows that it was possible to

\footnotetext{
82 Ibidem, p. 21.

${ }^{83}$ Ibidem, pp. 34-35.

84 Ibidem, p. 86.

85 Ibidem, p. 95.

${ }^{86}$ Ibidem, p. 114.

87 Ibidem, p. 26.

88 Ibidem, p. 42.

89 Ibidem, p. 48.

90 Ibidem, p. 58.

91 Ibidem, p. 59.

92 Ibidem, p. 77.

93 Ibidem.

94 Ibidem, p. 78.

95 Ibidem, p. 108.

96 Ibidem, p. 160.
} 
educate women to hold high executive positions and become exemplary for her extraordinary problem solving capacity.

Now let us consider some of the dialogues of Nasser Khosrow, which occupy very small space. In the city of Mo'arat ol-No'mân he asks about a heavy cylinder which was placed at the entrance of the town. They told him that it was a talisman against dragons never to enter their town. ${ }^{97}$ In this same city he realized that the headman of the city was a blind man, who had lots of servants and executives who performed the tasks of municipality and consulted him only for the most important items. He was a poet and a man of God and he himself had 100,000 verses of poetry, and he always had some 200 literary men around him. He sat on a mat at the door of his house, and his only food was barley bread. ${ }^{98} \mathrm{He}$ had written a book called Alfosul va Alqâyât and "no one is at his stature in poetry and literature in Damascus, Morocco and Iraq". His book is so important that "some said he had written his book in competition with the holy Koran". This is the best Nasser Khosrow says about one person in any location.

Nasser Khosrow gives the professions of Cairo as the following: Sultan, prime minister, chief judge, men of science, government executives. ${ }^{99}$ In the city of Asvân he spoke to a man and he says that he was religious and had knowledge of logic. ${ }^{100}$ In the city of Bajâhân, about which we wrote before-people asked Nasser Khosrow to deliver lectures for them. ${ }^{101}$

Naturally going from a city to the next, from a group to the next could be dangerous, but we see his reckoning of a scientist that he knows, opens the doors for him. ${ }^{102}$ Thus we can see that relationship of men of sciences and knowledge would make trips feasible for him, and when obliged to stay in a location for four months, having books with him, made this long journey endurable. ${ }^{103}$

In the city of Lahsâ, he speaks about the chief called Busa'eedi who had prevented people becoming Moslems and did not allow them to pray or fast, and the people called themselves "Busa'eedi", and they behaved in great justice toward the farmers and lower classes, and people were not in opposition and feud against each other. Busa'eed had six ministers, and with his six sons, he reigned peacefully over his chiefdom. ${ }^{104}$

The only mention of acute emotion by Nasser Khosrow is the following: Entering Bassreh. He had not been able to shave his beard for three months and his face looked like idiots; so much so that he was not allowed to enter the bath house. ${ }^{105}$ Here he speaks about the sense of shame, a primal feeling. He thus leaves for the city of Ahvaz where he knew a minister who was a learned man, and sends a message for him that he was in town. The latter sends him a sum of money he

\footnotetext{
${ }^{97}$ Ibidem, p. 13.

98 Ibidem.

99 Ibidem, p. 86.

100 Ibidem, p. 112.

101 Ibidem, p. 115.

102 Ibidem, p. 143.

103 Ibidem.

104 Ibidem, p. 148.

105 Ibidem, p. 155.
} 
goes to a bath house, and after twenty days he returns to Bassreh and goes to the same bath house, and writes about the sense of shame that the guardian expresses upon seeing him. ${ }^{106}$ This primal sense of emotions is the only time that during this seven year trip he writes about. In the city of Mahrubân he was in contact with men of learning. Apparently there was a network of men of science and knowledge, and he was known to them and he used this network in his travels.

At the end of his voyage of seven years, when he gets close to his home town of Balkh, some people ask about them, three men who had left seven years before and wanted to see if they had any news about them. ${ }^{107}$ Nasser Khosrow only said: "we were happy and thankful to meet each other". ${ }^{108}$ Then he sent his brother to report their return and the book ends with "whatever I saw, I have truly reported". ${ }^{109}$

\section{Conclusion}

Anthropology has been looking at human life in various environments, with different histories, in relation to surrounding peoples, and tries to understand what different "wisdoms" they have acquired, and how they have been helpful to continued existence of human beings. It would need another undertaking of Nasser Khosrow writings after this trip to see how, indeed, his views have changed, and how these seven years have taken him toward the true wisdom he was looking for when he set out for this trip. This would help us establish him as a thinker within the tradition of anthropology, before it was established in the European world. In any event, what is beyond question is that students of various sub-fields of anthropology should consult him: anthropology of architecture, art, city planning, political, economic, pastoral nomads, war, ethnicity, medical, and the new fields of emotional anthropology, and disaster anthropology, because of his mention of natural orders and war. As mentioned above he did consider issues of justice, and security of communities.

\section{Bibliography}

Diamond S., In Search of the Primitive, Dutton 1974.

Nâser-e Khosrow-e Qobâdiyâni, Safarnâme, ed. M. Dabir Siaqi, Tehrân 1389/2006.

Radin P., Primitive Man as Philosopher, Dover 1927/1957.

Shahshahani S. Meymand, We Were One People, One Territory, Kerman 1384/2005.

\footnotetext{
${ }^{106}$ Ibidem, p. 157.

107 Ibidem, p. 173.

108 Ibidem.

109 Ibidem, p. 174.
} 